
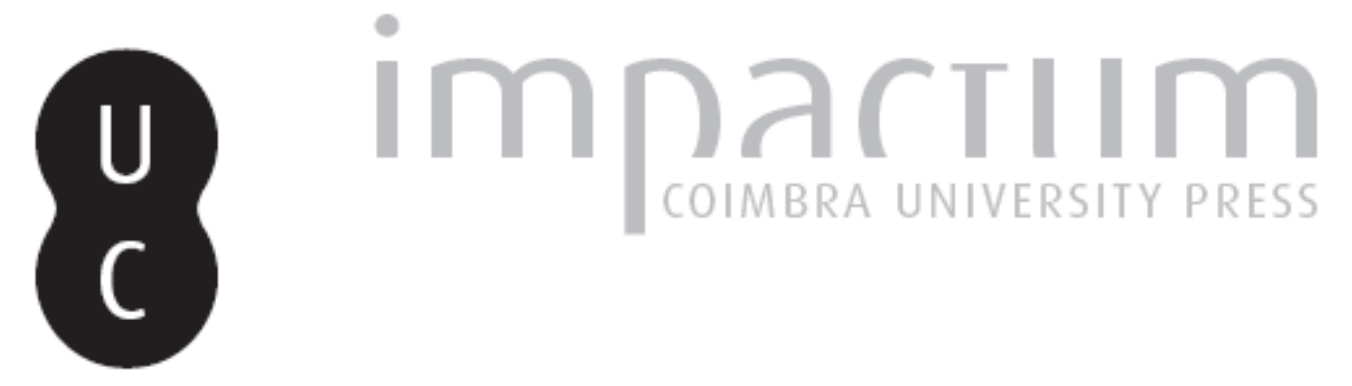

Entheseal changes: the role of Portuguese research

Autor(es): Henderson, Charlotte Yvette; Cardoso, Francisca Alves

Publicado por: Imprensa da Universidade de Coimbra

URL persistente:

URI:http://hdl.handle.net/10316.2/42118

DOI:

DOI:https://doi.org/10.14195/2182-7982_32_1

Accessed : $\quad$ 26-Apr-2023 14:31:14

A navegação consulta e descarregamento dos títulos inseridos nas Bibliotecas Digitais UC Digitalis, UC Pombalina e UC Impactum, pressupõem a aceitação plena e sem reservas dos Termos e Condições de Uso destas Bibliotecas Digitais, disponíveis em https://digitalis.uc.pt/pt-pt/termos.

Conforme exposto nos referidos Termos e Condições de Uso, o descarregamento de títulos de acesso restrito requer uma licença válida de autorização devendo o utilizador aceder ao(s) documento(s) a partir de um endereço de IP da instituição detentora da supramencionada licença.

Ao utilizador é apenas permitido o descarregamento para uso pessoal, pelo que o emprego do(s) título(s) descarregado(s) para outro fim, designadamente comercial, carece de autorização do respetivo autor ou editor da obra.

Na medida em que todas as obras da UC Digitalis se encontram protegidas pelo Código do Direito de Autor e Direitos Conexos e demais legislação aplicável, toda a cópia, parcial ou total, deste documento, nos casos em que é legalmente admitida, deverá conter ou fazer-se acompanhar por este aviso. 


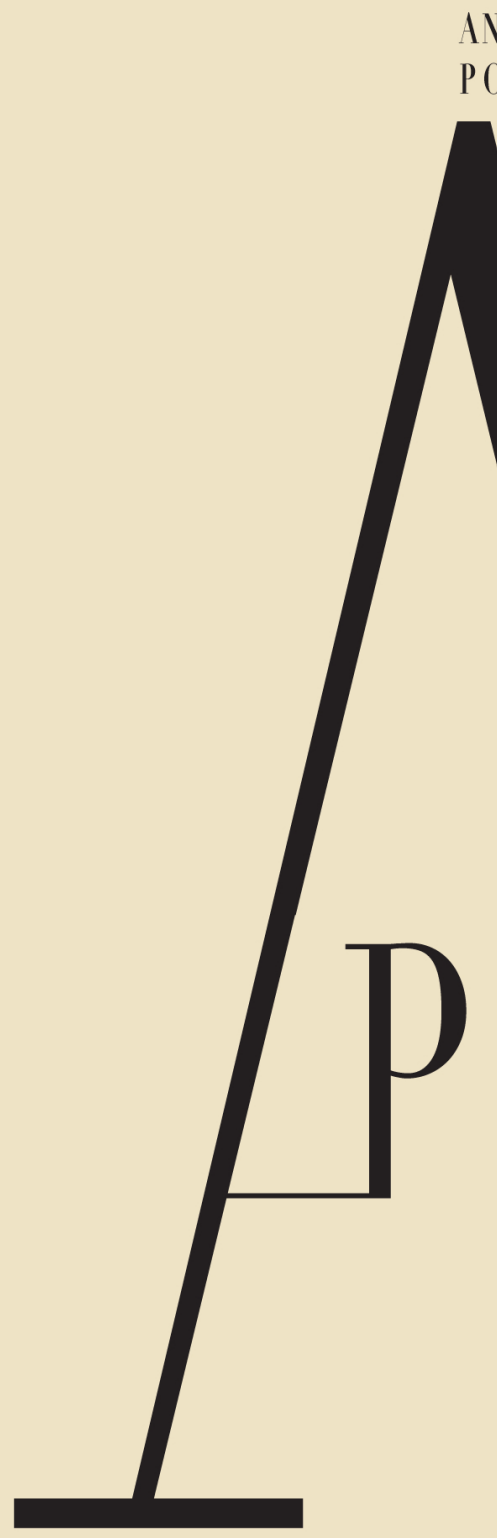

ANTROPOLOGIA

PORTUGUESA 


\section{Entheseal changes: the role of Portuguese research}

\section{Alterações das enteses: o papel das investigações portuguesas}

\section{Charlotte Yvette Henderson ${ }^{1 *}$, Francisca Alves Cardoso ${ }^{2}$}

\begin{abstract}
In this paper, we present a review of research in Portugal on entheseal changes (EC), widely used to record activity-patterns. This is explored chronologically and thematically, from the beginning of the research on EC addressing the development of research methods tested through their use in identified collections, which sought to infer if the physical activity leads to EC, to a workshop in 2009, dedicated to EC, through to the recently published outputs of the working groups set up at that meeting. We will also discuss the role of individuals and the world class identified skeletal collections. Key trends include the systematic development of recording methods, their testing and
\end{abstract}

Resumo No presente trabalho, apresenta-se uma revisão da investigação desenvolvida em Portugal no que concerne ao tema das alterações das enteses (AE), que têm sido amplamente utilizadas para registar padrões de atividade em populações do passado. O tema é explorado cronológica e tematicamente, desde o início da investigação em AE centrado no desenvolvimento de métodos testados em coleções osteológicas identificadas, que procuraram inferir se a atividade física seria responsável pela presença de $A E$, até às recentes publicações dos vários grupos de trabalho que tiveram origem no workshop de 2009. Será também discutida a importância dos investigadores

\footnotetext{
${ }^{1}$ Centro de Investigação em Antropologia e Saúde, Departamento de Ciências da Vida, Faculdade de Ciências e Tecnologia, Universidade de Coimbra, Coimbra, Portugal.

2 NOVA CRIA - Centro em Rede de Investigação em Antropologia, Faculdade de Ciências Sociais e Humanas, Universidade Nova de Lisboa, Lisboa, Portugal.

${ }^{*}$ Corresponding author: c.y.henderson@uc.pt
}

DOI: https://doi.org/10.14195/2182-7982_32_1 
the interrogation of the interplay of biology and society in occupation. The recent outputs of all the working groups will inform current and future research, meaning that the Portuguese role in the study of entheses will be long-lived and continue to be of international significance.

Keywords: Entheseal changes (EC); entheses; musculoskeletal stress markers (MSM); biomechanics; markers of occupational stress (MOS); identified skeletal collections.

\section{Introduction}

There have been several reviews of the history of the study of entheseal changes (EC) in recent years, all focussing on global perspectives (Jurmain et al., 2012; Schlecht, 2012; Henderson and Alves Cardoso, 2013). The aim in this paper is to focus more narrowly on Portugal to identify trends in research as well as to describe the use of Portuguese material for these studies. The purpose of this is to underline the vital role that Portuguese based research, specifically in association with the Portuguese Research Centre for Anthropology and Health (CIAS) and e das coleções osteológicas identificadas no estudo das AE. Presentemente, as principais tendências no estudo das $A E$ incluem o desenvolvimento de métodos de registo, a aferição da viabilidade e exequibilidade dos mesmos, e a discussão da relação entre biologia e sociedade associada ao conceito de ocupação. Os resultados dos grupos de trabalho refletem o estado da arte atual e informam sobre investigações futuras, evidenciando que o papel da investigação associada a Portugal no estudo das AE será de contínua relevância internacional.

Palavras-chave: Alterações das enteses $(\mathrm{AE})$; enteses; marcadores de stresse musculosquelético (MSM); biomecânica; marcadores de stresse ocupacional (MSO) coleções de esqueletos identificados.

Centre for Research in Anthropology (CRIA), has played in moving this field of research forward. This will be explored in terms of research undertaken both within Portugal and by Portuguese researchers as well as by meetings hosted and other activities. The need for future research will also be described along with the role that Portuguese based research could play within this.

Entheseal changes are any change to the normal visual appearance of the enthesis. An enthesis is the skeletal attachment of the musculoskeletal soft tissues, e.g. ligaments, tendons, and joint capsule, as well as being functionally 
associated with other neighbouring structures (Benjamin et al., 2002; 2004; Tan et al., 2007). Entheses are fibrous or fibrocartilaginous, although this is a simplification since fibrous sometimes contains fibrocartilaginous regions and vice versa (Benjamin et al., 2002). These changes can be seen on skeletal remains as mineralised tissue formation, surface discontinuity and complete loss of normal morphology (Henderson et al. 2015a; Villotte et al., 2016). Such changes have been widely used to infer activitypatterns in past populations either very specific, e.g. archery (Tihanyi et al., 2015), or more commonly general levels of activity and differences within populations (Campanacho and Santos, 2013; Havelková et al., 2013) and between populations (Henderson, 2013a; Villotte and Knüsel, 2014). In forensic anthropology, they have been used to assist identification either from activity (Cunha, 2006) or body mass (Godde and Taylor, 2011; 2013). Their use has, therefore, become widespread for both archaeological and other anthropological purposes. This is despite the fact that numerous factors are associated with their presence, ageing and body size being particularly important ( $F$. Cardoso, 2008; Cardoso and Henderson, 2010; Milella et al., 2012; Cardoso and Henderson, 2013; Henderson and Nikita, 2015; Michopoulou et al., 2015), and that their aetiology is not fully understood
(Henderson, 2008; 2009; Jurmain et al., 2012; Henderson, 2013b; Villotte et al., 2016). We will now take a step back in time to discuss some of the key reasons that Portugal has become an important research setting for the study of EC and then focus on recent and current research.

\section{Looking into the past}

The identified skeletal collections which exist in Portugal are not unique, they have counterparts in many other countries (for example Mariotti et al., 2004; Hunt and Albanese, 2005; Eliopoulos et al., 2007; Rissech and Steadman, 2011; Alemán et al., 2012; Watkins, 2012; ChiKeb et al., 2013). Such collections contain the documentary evidence necessary to standardise variables like age and sex and test the impact of others, e.g. occupation, on skeletal changes ( $F$. Cardoso, 2008; Cardoso and Henderson, 2013). However, as early as 1995, before EC research started to become widespread (for a review see Jurmain et al., 2012) just after the publication of a recording method by Hawkey and Merbs (1995), the association between EC and occupation was already being tested on an identified skeletal collection, specifically at Coimbra University (Cunha and Umbelino, 1995). These authors used a method developed 
in France in the 1980s (Crubézy, 1988) which, contrary to Hawkey and Merbs's method, has not become widespread outside of continental Europe (Jurmain et al., 2012). They found, using a slight modification of Crubézy's method, that EC were predominantly age-related (Cunha and Umbelino, 1995).

Two key steps followed this. A more widely used method (Hawkey and Merbs, 1995) was applied to the Coimbra collection and to an identified skeletal collection in Lisbon (H. Cardoso, 2008). This was the first test of this method where age, sex and occupation could be controlled and, based on the contemporaneous literature, it was expected that differences between occupational categories would be found. However, the results were not as straightforward as expected because the differences found between occupational groups were predominantly the effect of dissimilar age profiles of those occupations (F. Cardoso, 2008). The implications of this will be described in the following section. Contemporary to this, two doctoral students (Villotte, 2008; Henderson, 2009) were taking a step back and using the anatomical and other clinical literature to develop new methods for recording EC. Henderson did not use Portuguese material, but she and F. Cardoso were contemporaries during their doctoral research with the same supervisor, Professor Roberts, at Durham University, UK, leading to many discussions and subsequent collaborations. In contrast, Villotte used identified skeletal collections in Portugal, and elsewhere, to develop a new biologically appropriate visual recording method (Villotte, 2008; Villotte et al., 2010). As with all other methods, this approach is affected by age, but a generalised linear model was created which separated the heavy manual workers from the other occupations (Villotte et al., 2010; Henderson and Nikita, 2015).

The combination of negative and positive results and the overlap in collection usage led to the decision to hold a workshop in Coimbra, in 2009, to bring together all those working in this research area. In the year prior to 2009, it had become clear that research based on skeletal changes referred to as occupational markers, as well as musculoskeletal stress markers, was gaining massive popularity within the academic community dedicated to the reconstruction of past behaviour, without careful consideration for the limitations of such changes. Hence, the workshop was entitled "Musculoskeletal Stress Markers (MSM): Limitations and achievements in the reconstruction of past activity patterns ${ }^{\prime \prime}$, and it aimed at fostering a productive environment for discussion of the methodologies and

${ }^{1}$ Available at: http://cias.uc.pt/workshop-musculoskeletal-stress-markers-msm/ 
terminology employed in the study of musculoskeletal stress markers (now renamed EC), and if these served as the best indicators of occupational stress. Presentations at the workshop and initial outcomes have been reported upon (Santos et al., 2011). As stated in Santos and colleagues paper, as an outcome of the workshop, three working groups were set up to standardise terminology, standardiseand createimproved methods for grouping occupations into categories, and the final one to create a standardised biologically appropriate recording method (Santos et al., 2011). The next section will focus on how these groups have progressed and contextualise this by other research within Portugal and on Portuguese collections.

\section{Since 2009}

The initial triumph of the working groups set up after the Coimbra workshop was that of the Working Group on Terminology. The two members of this group developed new terminology for changes associated with the enthesis sites, based on the anatomical and clinical literature (Jurmain and Villotte, 2010). The aim was to avoid the inherent aetiology incorporated into the term most commonly used to describe EC, i.e. musculoskeletal stress marker (MSM).
The term coined (and used throughout this and the majority of other recent papers) is entheseal changes (EC). The paper also outlines a review of other clinical terms for some of the types of EC. Moreover it demonstrates the value of the webpages set up after the Coimbra meeting to host this material and other relevant information (including the original conference programme and many of the presentations) (Santos at al, 2009), which have been widely consulted as evidenced by the almost universal use of this term, i.e. EC, in recent years.

With the demonstration that the most widely used recording method (Hawkey and Merbs, 1995) was both biologically inappropriate and did not differentiate between occupational groups, new approaches had to be put in place. One option was to convert the scores derived from this method, which were essentially ordinal, into a dichotomous assessment of the changes, i.e. presence and absence (Cardoso and Henderson, 2010). However, this can only be undertaken for fibrocartilaginous entheses because the variability in normal morphology of fibrous entheses means that there is currently no biologically appropriate method for scoring these as present or absent (Cardoso and Henderson, 2010; Jurmain et al., 2012). Once the data from the identified collections had been recorded, logistic regression was used to determine whether occupation affected 
EC presence when age was controlled. As with two previous attempts (Cunha and Umbelino, 1995; F. Cardoso, 2008) age was the primary factor in EC presence. However, the second working group set out to standardise occupation and this was yet to be reported in 2010 (Santos et al, 2009).

The standardisation of occupation is important. Clear discrepancies exist between the methods used by those who have used identified skeletal collections to test their methods (Cunha and Umbelino, 1995; Mariotti et al., 2004; 2007; Cardoso and Henderson, 2010; Villotte et al., 2010; Milella et al., 2012; Henderson et al., 2013a; Perréard Lopreno et al., 2013; Henderson and Nikita, 2015). Some have used socioeconomic factors, while others have attempted to categorise the amount of loading. A review of these methods was the first output of the Working Group on Occupation (Perréard Lopreno et al., 2013). This was initially presented as a poster at the Annual Meeting of the American Association of Physical Anthropologists in 2012, at a symposium entitled "Working Nine to Five: The future of activity-related stress", organised and chaired by two postdoctoral researchers working in Portugal, at the research centres of CIAS and CRIA (Henderson and Alves Cardoso, 2012). The presentations of this symposium were subsequently collated into a special issue of the
International Journal of Osteoarchaeology (Henderson and Alves Cardoso, 2013).

In the same issue, the method for categorisation of occupation was also tested using data previously collected on Portuguese identified collections. Three methods of categorisation of occupation were used and all demonstrated that ageing was the primary factor in EC presence for the fibrocartilaginous entheses recorded using a presence and absencemethod(CardosoandHenderson, 2013). What is clear from this is that it is not just the method of categorisation that is problematic; EC scoring methods may also introduce biases.

Recording methods have typically scored a variety of features or zones which are pooled together to create a composite score describing the EC at the enthesis (Hawkey and Merbs, 1995; Mariotti et al., 2004; Villotte, 2006; Mariotti et al., 2007). Presence and absence methods work similarly, but only note the presence of any change (for fibrocartilaginous entheses only) from the normal smooth, wellcircumscribed surface devoid of pores (Henderson, 2009). To put this more simply all visual recording methods pool a variety of changes and the locations of these changes into one final score which does not describe the variability in types of changes seen at entheses. It should be noted that non-visual recording methods have also been developed 
but have yet to become widely used (Henderson, 2013b; Noldner and Edgar, 2013; Nolte and Wilczak, 2013). Two biologically appropriate recording methods have been in existence since the 2000s (Villotte, 2006; Henderson, 2009; Jurmain et al., 2012), neither of these methods provide any indication in the final score about the types of changes present. The aim of the Working Group on Methodology was, therefore, to develop a method for recording all features of EC in a biologically appropriate way with the objective to use this to improve our understanding of what causes these changes and how each relates to known causative factors, specifically the ageing process (Henderson et al., 2013b; Henderson et al., 2015a). Currently, the only change with a known mechanism of formation is the enthesophyte, or spur, other changes involving mineralised tissue formation, destruction or complete morphological change are poorly understood (Villotte et al., 2016). The aim, therefore, was not to develop a pooled scoring system, but to record each feature separately and, once our understanding of the processes causing these changes improves, to develop a composite score using the method (Henderson et al., 2013b; 2015a).

The Working Group on Methodology has since been working and testing what is now called the new Coimbra method. It uses the range of variability tissue formation and destruction (with scope to describe other changes) to describe changes in the most fibrous portion of the fibrocartilaginous enthesis (zone 1) and in the remaining area (zone 2) (Henderson et al., 2013b). This method was developed during a workshop for the Working Group on Methodology held in Geneva in 2010. However, this workshop was short and issues of interobserver reliability were immediately apparent (Henderson et al., 2013b).

It was decided, due to the poor reliability of the new method and other work pressures of all members of the working groups that the members needed a single meeting to enable them to work towards the common and individual group's (i.e. terminology, occupation and methodology) goals. For this reason, a workshop was arranged (organised by the authors, and Villotte and Perréard Lopreno, funded by a Wenner-Gren foundation grant CONF632 and supported by CRIA and CIAS research centres) and held in Coimbra in 2013 solely for the members of the working groups. Each group had an aim to work towards, described below. During the meeting the groups worked separately towards these specific goals, but also spent time together with presentations on aims, methodology and results for open discussion and input from the other participants. This enabled the participants to utilise the full breadth 
and depth of everybody's knowledge for each group's goals.

The goal of the Working Group on Terminology was to develop a classification system and standard terms for each type of EC and to translate this into common modern European languages, including Portuguese (Villotte et al., 2016). During the meeting, the team used clinical and anatomical texts to identify the most appropriate terms for the features. This new classification and naming system will enable improved communication between researchers describing EC, which is vital to advance the understanding of the variability in changes seen at entheses (some changes are more common at some entheses than others) (Henderson et al., 2015a), their age and population distribution. This new paper also raises awareness of the current limitations in the knowledge of EC and their aetiology, demonstrating the need for further research and larger data sets.

The Working Group on Terminology also worked closely with the Working Group on Methodology to better the terms used to describe EC features. Prior to the workshop, the working group had attempted to improve the inter-observer error reliability and discuss changes using photographs, but numerous limitations were discovered, particularly the magnification of images on the screen and the difficulty of seeing all aspects of three-dimensional structures in single two dimensional images. However, despite this, progress was made, particularly in highlighting areas which the team needed to focus on during the meeting, e.g. clarifying the outline of the enthesis that needs to be scored. The outline of the enthesis footprint was clarified during the meeting which immediately reduced some recording differences between observers. Seriation was also used to determine at which point a feature went from not present (score 0) to a score of 1 or 2 . The method was tested by the working group members at the end of the meeting and reliability had improved from the previous incarnation (Henderson et al., 2015a; Wilczak et al., 2017).

The previous outputs of the Working Group on Occupation showed the wide variety of occupational categorisation methods that had been used. During the workshop, participants took a different approach, focussing on using principal components and cluster analysis on data previously collected on identified skeletons (Italian and Portuguese) to determine how occupations clustered based on the presence of EC in the upper limb without prior assumptions of occupation groupings (Milella et al., 2015). What was most striking was that occupations which have often previously been considered in different categories, when based on perceptions of loading, clustered 
together. The results framed three major groups of individuals originally dedicated to farming, another group dedicated to physically demanding but more generalized occupation, and another set of people employed in less physically demanding occupations. Major and consistent differences were found between individuals working in farming, and the latter group. These results highlighted the physical and social specificity of farming and related activities. Therefore, as far as general development of EC was concerned, data suggest a lower degree of reliability between EC and occupation. Therefore, EC are useful only when discussing general patterns of biomechanical stress. Moreover, the method used demonstrates the usefulness of using big data and using data mining techniques to study relationships without a priori expectations.

\section{Since 2013}

The time lag on publishing after meetings means that the results and implications of the working groups' outputs have yet to make a big impact on the current research paradigm of EC. The first workshop providing training in the new method was run in 2014 in the CIAS in conjunction with the IV Jornadas
Portuguesas de Paleopatologia. Currently, the most popular method for recording entheses in Portugal is a non-biologically appropriate method developed in Italy (Mariotti etal., 2004; 2007) which is known, like all methods, to be affected by ageing (Milella et al., 2012). Several masters' theses (e.g. Inocêncio, 2013; Fidalgo, 2014; Gil, 2014; Pereira, 2015) have used this method to identify and score changes found in Chalcolithic and Bronze Age burials and cremated bones. However, broad conclusions about population variability (or activity-patterns) cannot be drawn due to the highly fragmentary nature of the remains.

Other research undertaken in Portugal has demonstrated that trends through time in EC indicate that those living in industrial societies have higher scores for EC than those living in either hunter-gatherer or agricultural communities, with those in the latter having the lowest scores (Henderson, 2013a). However, this is partly dependent on methodology used to record changes and does require further analysis. More recent data, including other recording methods, indicate that hunter-gatherers have lower scores than agriculturalists, but that industrialists remain the highest (Henderson, 2015). However, the demographic profiles of the samples included may have an impact on these results (Henderson, 2013a; 2015). Until the new Coimbra recording method 
becomes widespread, the variability of these changes and how they relate to these subsistence strategies cannot be ascertained.

Work continues to be undertaken on studying $\mathrm{EC}$ in relation to occupation and poverty (Henderson et al., 2015b). On the relationship between enthesis size, shape, age, body size and occupation, preliminary results indicate that, in individuals under 36 years of age, there is no effect of ageing but neither do entheses indicate occupation (Henderson, 2014a; 2014b; 2014c). Results for the association between skeletal development, ageing, occupation and EC features are expected in 2016. Researchers in Portugal continue to work on this area, but, more importantly, the outcomes from work associated with Portugal, i.e. either research by Portuguese researchers or using collections bases in Portugal, are becoming more widely used. It is, therefore, certain that Portuguese based research will continue to play a significant role in $\mathrm{EC}$ research, answering the many questions which remain surrounding their aetiology and the variability of their expression.

\section{Conclusions}

Without the research undertaken on EC in the last two decades in
Portugal, specifically in CIAS and CRIA, the terms now used to describe EC, our understanding of their aetiology, their association with ageing and the methods used to record them would not have progresses so far or so rapidly. It is clear that meetings set up in 2009 and 2013 have really pushed the field forward and made an international impression. In the 2009 meeting, 21 countries were represented by contributors. The working groups set up during this meeting consist of researchers currently working in Portugal, the United Kingdom, France, Austria, Italy, Switzerland, and the United States of America (Villotte et al., 2016). Therefore, the research from the working groups has an immediately global impact and has been widely cited internationally. Portugal, therefore, is punching well above its weight in this area of research and, given the wide interest in this area, will continue to do so for the foreseeable future.

\section{Acknowledgements}

The authors wish to thank the Fundação para a Ciência e a Tecnologia for funding (supported by the European Commission ESF and POPH) their research with a postdoctoral bursary to Henderson (SFRH/BPD/82559/2011), and a postdoctoral bursary (SFRH/ 
BPD/43330/2008) and a FCT Investigator Award Programme (IF/00127/2014) to Alves Cardoso. Both authors wish to thank their research institutions CIAS and CRIA for hosting them and for supporting the Wenner-Gren Foundation funded workshop in 2013 (CONF-632), as well as the other organisers, Sébastien Villotte and Geneviève Perréard Lopreno. Finally, the authors would like to thank their PhD supervisor, Prof. Charlotte Roberts, for support on research related with entheseal changes and paleopathology; and would further like to acknowledge Prof. Robert Jurmain, and other members of the working groups, for continued discussions and gratifying collaborations, none of which could have come about without the Workshop in 2009 organised by Ana Luísa Santos, Francisca Alves Cardoso, Sandra Assis and Sébastien Villotte.

\section{References}

Alemán, I.; Irurita, J.; Valencia, A. R.; Martínez, A.; López-Lázaro, S.; Viciano, J; Botella, M. C. 2012. Brief communication: the Granada osteological collection of identified infants and young children. American Journal of Physical Anthropology, 149(4): 606-610. DOI: 10.1002/ajpa.22165.

Benjamin, M.; Kumai, T.; Milz, S.; Boszczyk, B.; Boszczyk, A.; Ralphs, J. 2002. The skeletal attachment of tendonstendon "entheses". Comparative Biochemistry and Physiology Part A: Molecular and Integrative Physiology, 133(4): 931-945. DOI: 10.1016/S10956433(02)00138-1.

Benjamin, M.; Moriggl, B.; Brenner, E.; Emery, P.; McGonagle, D.; Redman, S. 2004. The "enthesis organ" concept: why enthesopathies may not present as focal insertional disorders. Arthritis Rheumatology, 50(10): 3306-3313. DOl: 10.1002/art.20566.

Campanacho, V.; Santos, A. L. 2013. Comparison of the entheseal changes of the os coxae of Portuguese males (19th-20th centuries) with known occupation. International Journal of Osteoarchaeology, 23(2): 229-236. DOI: 10.1002/oa.2297.

Cardoso, F. A. 2008. A portrait of gender in two 19th and 20th century Portuguese populations: a palaeopathological perspective. Doctoral thesis, Durham University. Available at: http://etheses. dur.ac.uk/1847/.

Cardoso, F. A.; Henderson, C.Y. 2010. Enthesopathy formation in the humerus: data from known age-atdeath and known occupation skeletal collections. American Journal of Physical Anthropology, 141(4): 550-560. DOI: 10.1002/ajpa.21171.

Cardoso, F. A.; Henderson, C. Y. 2013. The categorisation of occupation in identified skeletal collections: a source of bias? International Journal of 
Osteoarchaeology, 23(2): 186-196. DOI: 10.1002/oa.2285.

Cardoso, H. F. V. 2008. Age estimation of adolescent and young adult male and female skeletons II, epiphyseal union at the upper limb and scapular girdle in a modern Portuguese skeletal sample. American Journal of Physical Anthropology, 137(1): 97-105. DOI: 10.1002/ajpa.20850.

Chi-Keb, J. R.; Albertos-González, V. M.; Ortega-Munoz, A.; Tiesler, V. G. 2013. A new reference collection of documented human skeletons from Mérida, Yucatan, Mexico. HOMO - Journal of Comparative Human Biology, 64(5): 366-376. DOI: 10.1016/j. jchb.2013.05.002.

Crubézy, É. 1988. Interactions entre facteurs bio-culturels, pathologie et caractères discrets: exemple d'une population mediévale: Canac (Aveyron). Doctoral thesis, Université Montpellier 1.

Cunha, E. 2006. Pathology as a factor of personal identity in forensic anthropology. In: Schmitt, A.; Cunha, E.; Pinheiro, J. (eds.) Forensic Anthropology and Medicine. Totowa, NJ, Humana Press: 333-358. DOI: 10.1007/978-159745-099-7_14.

Cunha, E.;Umbelino, C. 1995. Whatcan bonestell aboutlabourand occupation:theanalysis of skeletal markers of occupational stress in the Identified Skeletal Collection of the Anthropological Museum of the University of Coimbra (preliminary results). Antropologia Portuguesa, 13:
49-68. Available at: http://hdl.handle. net/10316.2/30538.

Eliopoulos, C.; Lagia, A.; Manolis, S. 2007. A modern, documented human skeletal collection from Greece. HOMO - Journal of Comparative Human Biology, 58(3): 221-228. DOI: 10.1016/j. jchb.2006.10.003.

Fidalgo, D. F. F. 2014. Contextos funerários e estudo antropológico dos restos ósseos humanos dos hipogeus de Torre Velha 3 (São Salvador, Serpa): uma aproximação ao estudo das comunidades humanas do Bronze doSudoeste. Masters dissertation, Departament of Life Sciences, Faculty of Sciences and Technology, University of Coimbra. Available at: http://hdl. handle.net/10316/27862.

Gil, P. A. A. 2014. Necrópoles de Cistas na realidade do Sudoeste Peninsular durante o Il milénio aC: práticas funerárias e análise antropológica dos restos ósseos humanos exumados das Necrópoles de Casas Velhas e Monte da Cabida 3 Masters dissertation, Departament of Life Sciences, Faculty of Sciences and Technology, University of Coimbra. Available at: http://hdl.handle. net/10316/27864

Godde, K.; Taylor, R. W. 2011. Musculoskeletal stress marker (MSM) differences in the modern American upper limb and pectoral girdle in relation to activity level and body mass index (BMI). Forensic science international 210(1-3): 237-242. DOI: 10.1016/j. forsciint.2011.03.014 
Godde, K.; Taylor, R. W. 2013. Distinguishing body mass and activity level from the lower limb: can entheses diagnose obesity? Forensic Science International, 226(1-3): 303.e1-303.e7.DOI: 10.1016/j. forsciint.2013.01.027.

Havelková, P.; Hladík, M.; Velemínský, P. 2013. Entheseal Changes: do they reflect socioeconomic status in the early medieval Central European population? (Mikulčice - Klášteřisko, Great Moravian Empire, 9th-10th century). International Journal of Osteoarchaeology, 23(2): 237-251. DOI: 10.1002/oa.2294.

Hawkey, D. E.; Merbs, C. F. 1995. Activityinduced musculoskeletal stress markers (MSM) and subsistence strategy changes among ancient Hudson Bay Eskimos. International Journal of Osteoarchaeology, 5(4): 324-338. DOI: 10.1002/oa.1390050403.

Henderson, C. Y. 2008. When hard work is disease: the interpretation of enthesopathies. In: Brickley, M.; Smith, M. (eds.) Proceedings of the Eighth Annual Conference of the British Association for Biological Anthropology and Osteoarchaeology. Oxford, British Archaeological Reports, International Series 1743: 17-23.

Henderson, C. Y. 2009. Musculo-skeletal stress markers in bioarchaeology: indicators of activity levels or human variation?: a re-analysis and interpretation. Doctoral thesis, Durham University. Available at: http://etheses.dur.ac.uk/1953/.
Henderson, C. Y. 2013a. Subsistence strategy changes: the evidence of entheseal changes. HOMO - Journal of Comparative Human Biology, 64(6): 491-508. DOl: 10.1016/j. jchb.2013.08.002.

Henderson, C. Y. 2013b. Technical note: quantifying size and shape of entheses. Anthropological Science, 121(1): 63-73. DOI: 10.1537/ase.121017.

Henderson, C. Y. 2014a. The effect of entheseal changes on size of the enthesis in young adults. IV Jornadas Portuguesas de Paleopatologia, Coimbra, Portugal, 21 th - 22th November, 2014. [Acessed 10-10-2015]. Available at: http://www.uc.pt/en/cia/grupos/ app/Posters/PCPposteres2014/ Henderson__2014c.pdf.

Henderson, C. Y. 2014b. Entheseal changes: youth and work. 16th Annual Conference of the British Association for Biological Anthropology and Osteoarchaeology, Durham, UK, 12th - 14th September, 2014. [Acessed 10-10-2015]. Available at: http://www.uc.pt/en/cia/grupos/ app/Posters/PCPposteres2014/ Henderson_2014b.pdf.

Henderson, C. Y. 2014c. The value of skeletal remains for understanding entheses. Bone Research Society Annual Meeting, Sheffield, UK, 25th - 26th June, 2014. [Acessed 10-10-2015]. Available at: http://www.uc.pt/en/cia/grupos/ app/Posters/PCPposteres2014/ Henderson_2014a.pdf.

Henderson, C. Y. 2015. Opposites react: a 
meta-analysis of entheseal changes. In: 17th Annual Conference of the British Association for Biological Anthropology and Osteorchaeology. Sheffield, UK, 18th -20th September, 2015. [Acessed 10-102015] Available at: www.researchgate. net/publication/282075836_ Opposites_React_A_meta-analysis_ of_entheseal_changes.

Henderson, C. Y; Alves Cardoso, F. 2012. Working nine to five: the future of activity-related stress. American Journal of Physical Anthropology, 147(S54): 85. DOI: 10.1002/ajpa.22033.

Henderson, C. Y.; Alves Cardoso, F. 2013. Preface to special issue entheseal changes and occupation: technical and theoretical advances and their applications. International Journal of Osteoarchaeology, 23(2): 127-134. DOI: 10.1002/oa.2298.

Henderson, C. Y.; Nikita, E. 2015. Accounting for multiple effects and the problem of small sample sizes in osteology: a case study focussing on entheseal changes. Archaeological and Anthropological Sciences [Online]. DOI: 10.1007/s12520015-0256-1.

Henderson, C. Y.; Craps, D. D.; Caffell, A. C.; Millard, A. R.; Gowland, R. 2013a. Occupational mobility in 19th century rural England: the interpretation of entheseal changes. International Journal of Osteoarchaeology, 23(2):197210. DOI: 10.1002/oa.2286.

Henderson, C. Y.; Mariotti, V.; Pany-Kucera, D.; Villotte, S.; Wilczak, C. 2013b.
Recording specific entheseal changes of fibrocartilaginous entheses: initial tests using the Coimbra Method. International Journal of Osteoarchaeology, 23(2): 152-162. DOI: 10.1002/oa.2287.

Henderson, C. Y.; Mariotti, V.; Pany-Kucera, D.; Villotte, S.; Wilczak, C. 2015a. The new "Coimbra Method": a biologically appropriate method for recording specific features of fibrocartilaginous entheseal changes. International Journal of Osteoarchaeology, 26(5); 925-932. DOI: 10.1002/oa.2477.

Henderson, C. Y.; Alves Cardoso, F.; Assis, S. 2015b. Poverty and work: integrating skeletal and documentary evidence in nineteenth century Portugal. $21^{\text {st }}$ Annual Meeting of the European Association of Archaeologists, Glasgow, 2nd - 5th September, 2015 [Acessed 10-10-2015]. Available at https://www.researchgate. net/publication/281646941_Poverty_ and_work_integrating_skeletal_ and_documentary_evidence_in_ nineteenth_century_Portugal?ev=prf_ pub.

Hunt, D. R.; Albanese, J. 2005. History and demographic composition of the Robert J. Terry anatomical collection. American Journal of Physical Anthropology, 127(4): 406-417. DOI: 10.1002/ajpa.20135.

Inocêncio, J. R. P. 2013. Contextos e práticas funerárias calcolíticas no Baixo Alentejo Interior (Sudeste Alentejano). Masters dissertation, Universidade do Minho, 
Instituto de Ciências Sociais. Available at: http://hdl.handle.net/1822/29297.

Jurmain, R.; Villotte, S. 2010. Terminology. Entheses in medical literature and physical anthropology: a brief review. [Online] Coimbra [Acessed 5-10-2015]. Available at: http://www.uc.pt/en/cia/ events/msm/MSM_terminology.

Jurmain. R.; Alves Cardoso, F.; Henderson, C.; Villotte, S. 2012. Bioarchaeology's Holy Grail: the reconstruction of activity. In: Grauer, A. (ed.) A companion to Paleopathology. Chichester, Blackwell Publishing: 531-542.

Mariotti, V.; Facchini, F.; Belcastro, M. G. 2004. Enthesopathies - proposal of a standardized scoring method and applications.Collegium Antropologicum, 28(1): 145-159.

Mariotti, V.; Facchini, F.; Belcastro, M. G. 2007. The study of entheses: proposal of a standardised scoring method for twenty-three entheses of the postcranial skeleton. Collegium Antropologicum, 31(1): 291-313

Michopoulou, E.; Nikita, E.; Valakos, E. D.; 2015. Evaluating the efficiency of different recording protocols for entheseal changes in regards to expressing activity patterns using archival data and cross-sectional geometric properties. American Journal of Physical Anthropology, 158(4): 557-568. DOI: 10.1002/ajpa.22822.

Milella, M.; Belcastro, M. G.; Zollikofer, C. P. E.; Mariotti, V. 2012. The effect of age, sex, and physical activity on entheseal morphology in a contemporary Italian skeletal collection. American Journal of Physical Anthropology, 148(3): 379-388. DOI: 10.1002/ajpa.22060.

Milella, M.; Cardoso, F. A.; Assis, S.; Perréard Lopreno, G.; Speith, N. 2015. Exploring the relationship between entheseal changes and physical activity: A multivariate study. American Journal of Physical Anthropology, 156(2): 215-223. DOI: 10.1002/ajpa.22640.

Noldner, L. K.; Edgar, H. J. H. 2013. Technical note: $3 \mathrm{D}$ representation and analysis of enthesis morphology. American Journal of Physical Anthropology, 152(3): 417-424. DOI: 10.1002/ajpa.22367.

Nolte, M.; Wilczak, C. 2013. Three-dimensional surface area of the distal biceps enthesis, relationship to body size, sex, age and secular changes in a 20th century American sample. International Journal of Osteoarchaeology, 23(2): 163-174. DOI: 10.1002/oa.2292.

Pereira, D. 2015. Nas cinzas jazem engendros da morte, reflexos de vidas de outrora: as cremações pré-históricas dos Perdigões. Masters dissertation, Department of Life Sciences, Faculty of Sciences And Technology, University of Coimbra. Available at: http://hdl.handle. net/10316/28010.

Perréard Lopreno, G.; Alves Cardoso, F.; Assis, S.; Milella, M.; Speith, N. 2013. Categorization of occupation in documented skeletal collections: its relevance for the interpretation of activity-related osseous 
changes. International Journal of Osteoarchaeology, 23(2): 175-185. DOI: 10.1002/oa.2301.

Rissech, C.; Steadman, D. W. 2011. The demographic, socio-economic and temporal contextualisation of the Universitat Autònoma de Barcelona Collection of Identified Human Skeletons (UAB Collection). International Journal of Osteoarchaeology, 21(3): 313-322. DOI: 10.1002/oa.1145.

Santos, A. L.; Cardoso, F. A.; Assis, S.; Villotte, S. 2009. After the workshop on MSM. [Online]. Coimbra. [Accessed 5-102015]. Available at: http://cias.uc.pt/ workshopmusculoskeletal-stressmarkers-msm/.

Santos, A. L.; Alves Cardoso, F.; Assis, S.; Villotte, S. 2011. The Coimbra workshop in musculoskeletal stress markers (MSM): an annotated review. Antropologia Portuguesa, 28: 135-161. DOI: 10.14195/2182-7982_28_5.

Schlecht, S. H. 2012. Understanding entheses: bridging the gap between clinical and anthropological perspectives. Anatomical record, 295(8): 1239-1251. DOI: 10.1002/ar.22516.

Tan, A. L.; Benjamin, M.; Toumi, H.; Grainger, A. J.; Tanner, S. F.; Emery, P.; McGonagle, D. 2007. The relationship between the extensor tendon enthesis and the nail in distal interphalangeal joint disease in psoriatic arthritis - a highresolution $\mathrm{MRI}$ and histological study. Rheumatology (Oxford), 46: 253-256.
Tihanyi, B.; Bereczki, Z.; Molnár, E.; Berthon, W.; Révész, L.; Dutour, O.; Pálfi, G. 2015. Investigation of Hungarian Conquest Period (10th c. AD) archery on the basis of activity-induced stress markers on the skeleton — preliminary results. Acta Biologica Szegediensis, 59(1): 65-77.

Villotte, S. 2006. Connaissances médicales actuelles, cotation des enthésopathies : nouvelle méthode. Bulletins etmémoires de la Société d'Anthropologie de Paris, 18(1-2): 65-85.

Villotte, S. 2008. Enthésopathies et activités des hommes préhistoriques - recherche méthodologique et application aux fossiles européens du Paléolithique supérieur et du Mésolithique. Doctoral thesis, Université Sciences et Technologies, Bordeaux I. Available at: https://tel.archives-ouvertes.fr/tel00460387/.

Villotte, S.; Knüsel, C. J. 2014. "I sing of arms and of a man...": medial epicondylosis and the sexual division of labour in prehistoric Europe. Journal of Archaeological Science, 43: 168-174. DOI: 10.1016/j.jas.2013.12.009.

Villotte, S.; Castex, D.; Couallier, V.; Dutour, O.; Knüsel, C. J.; Henry-Gambier, D. 2010. Enthesopathies as occupational stress markers: evidence from the upper limb. American Journal of Physical Anthropology, 142(2): 224-234. DOI: 10.1002/ajpa.21217.

Villotte, S; Assis, S.; Cardoso, F. A.; Henderson, C. Y.; Mariotti, V.; Milella, M.; Pany-Kucera,D.; Speith, N.; Wilczak, C.; Jurmain, R. 2016. 
In Search of Consensus: terminology for Entheseal Changes (EC). International Journal of Paleopathology, 13: 49-55. DOI: 10.1016/j.jpp.2016.01.003.

Watkins, R. 2012. Variation in health and socioeconomic status within the $\mathrm{W}$. Montague Cobb skeletal collection: degenerative joint disease, trauma and cause of death. International Journal of Osteoarchaeology, 22(1): 22-44. DOI: 10.1002/oa.1178.

Wilczak, C.; Mariotti, V.; Pany-Kucera, D.; Villotte, S.; Henderson, C.Y. 2017. Training and Interobserver Reliability in Qualitative Scoring of Skeletal Samples. Journal of Archaeological Science: Reports, 11:6979. DOI: 10.1016/j.jasrep.2016.11.033. 